\title{
ASSOCIATION BETWEEN GLUTATHIONE S-TRANSFERASE OMEGA 1 A140D POLYMORPHISM IN THE TURKISH POPULATION AND SUSCEPTIBILITY TO NON-SMALL CELL LUNG CANCER
}

\author{
Tugba Guzide ADA ${ }^{1}$, Ahmet Oguz ADA ${ }^{1}$, Semih Celalettin KUNAK ${ }^{2}$, Sibel ALPAR ${ }^{3 a}$, \\ Meral GULHAN ${ }^{3 b}$, and Mumtaz ISCAN ${ }^{1}$
}

Department of Toxicology, Faculty of Pharmacy, Ankara University, Ankaral, Department of Pharmacology, Medical Faculty, Giresun University, Giresun'2, Pulmonary Diseases Clinic, Ataturk Pulmonary Diseases and Thoracic Surgery Hospital, Ankara ${ }^{3 b}$, Turkey

Received in August 2012

CrossChecked in November 2012

Accepted in December 2012

\begin{abstract}
Recent years have seen a growing evidence of ethnic differences in the frequency of glutathione S-transferase omega 1 (GSTO1) A140D gene polymorphism, which is associated with various cancers such as breast and liver. Until now however, no association has been investigated between the GSTO1 A140D polymorphism and lung cancer. The aim of our study was to see if there was one in the Turkish population. To do that, we identified GSTO1 A140D polymorphism in 214 unrelated healthy individuals and 172 patients with non-small cell lung cancer (NSCLC) using the polymerase chain reaction - restriction fragment length polymorphism (PCR-RFLP) method. The frequencies of A/A (wild type), A/D (heterozygous mutant), and D/D (homozygous mutant) GSTO1 A140D genotypes in healthy subjects were $48 \%, 41 \%$, and $11 \%$, respectively. In NSCLC patients they were $48 \%, 45 \%$, and $7 \%$, respectively. We found no significant association between the GSTO1 A140D gene polymorphism and NSCLC or its histological subtypes, namely squamous cell carcinoma or adenocarcinoma. Furthermore, this polymorphism did not correlate with smoking. Our study is the first to show that the frequency of GSTO1 A140D gene polymorphism in the Turkish population is similar to other Caucasian populations and that this polymorphism is not associated with susceptibility to NSCLC.
\end{abstract}

KEY WORDS: Caucasian, ethnic differences, gene polymorphism, NSCLC

Glutathione S-transferases (GSTs) is a superfamily of enzymes that play a key role in the protection of cells against numerous xenobiotics (including carcinogens) and oxidative stress (1). Human cytosolic

\footnotetext{
${ }^{a}$ Current address: Lokman Hekim Hospital,Sincan, Ankara, Turkey

${ }^{\mathrm{b}}$ Current address: Department of Chest Diseases, Ridvan Ege Hospital, Ufuk University, Ankara, Turkey
}

GSTs are divided into several classes according to their genetic and biochemical properties such as GST alpha, GST mu, GST theta, GST pi, and GST omega (2). Glutathione S-transferase omega 1 (GSTO1) is expressed in a wide range of human tissues, including the lungs $(3,4)$. It also plays a role in apoptosis $(5,6)$ and is a potential reservoir of intracellular glutathione 
(GSH), which protects against cellular oxidative stress $(4,5,7)$.

The protective role against cell toxicity can be weakened if enzyme activity is reduced, but the findings related to the GSTO1 gene polymorphism Ala140Asp/A140D are still inconclusive; TanakaKagawa et al. (8) have shown that it significantly reduces thiol transferase activity whereas Whitbread et al. (9) and Board and Anders (10) could not find any significant reduction in the enzyme activity resulting from aspartic acid substitution.

The frequency of GSTO1 A140D seems to vary between races $(9,11-18)$, but only a few studies investigated this frequency in Caucasians $(9,14,17$, 18). In the single study of GSTO1 A140D that included the Turkish population, Takeshita et al. (17) observed that its distribution differed from Caucasian populations, and was more similar to African, Eastern Asian, and Brazilian populations. However, this finding is challenged by a great variety in the distribution of the same gene polymorphism even within one population (19-22).

Recent studies have established an association between the GSTO1 A140D gene polymorphism and increased risk of breast, hepatocellular, bile duct, and urothelial cancer and acute lymphoblastic leukaemia in children $(13,23-25)$. In addition, several reports suggest that it may be associated with lung cancer in smokers (26-28). As about $80 \%$ of the lung cancer patients are non-small cell lung cancer (NSCLC) (29) and cigarette smoke has an important impact on the development of its subtypes such as adenocarcinoma (AC) and squamous cell carcinoma (SCC) $(30,31)$, it would be important to know if there were any association between this gene polymorphism and the risk of NSCLC. However, to our knowledge, no data is available in this regard. The aim of our study was therefore to establish the frequency of the GSTO1 $A 140 D$ polymorphism in the Turkish population and see whether this polymorphism was associated with susceptibility to NSCLC and its histological subtypes.

\section{SUBJECTS AND METHODS}

The study population consisted of 214 healthy controls and 172 patients with a histological diagnosis of the primary stage III or IV NSCLC, who were receiving platinum-based chemotherapy, as described elsewhere $(32,33)$. All subjects were genotyped for the GSTO1 A140D polymorphism, as determined by the polymorphic analysis of genomic DNA isolated from whole blood using the Promega Corporation (Madison, WI, USA) DNA purification kit and stored at $-20^{\circ} \mathrm{C}$ until use. GSTO1 A140D (rs4925) was determined with polymerase chain reaction - restriction fragment length polymorphism (PCR-RFLP) method described by Marahatta et al. (13). Repeated quality control analysis of randomly chosen $10 \%$ of the samples confirmed a $100 \%$ match.

All subjects were native Turkish Caucasians. Most were from the central Turkey, but also from other Turkish regions to represent the whole country. Healthy unrelated controls were selected from the general population. The exclusion criteria were pregnancy and present or previous history of malignancy. All subjects gave written informed consent, and completed a questionnaire with information on their sex, smoking, occupation, and health history. The study was approved by a local ethics committee.

\section{Statistical analysis}

Statistical analysis was performed using the SPSS 15.0 software (SPSS Inc., Chicago, IL, USA). We used Student's $t$-test to see if the two groups differred in age and smoking (using pack-years as the measure). To establish differences in the distribution of genotype/ allele frequencies between the groups we used the chi-square test and Fisher's exact test where necessary. The chi-square test was also used to see whether the frequency of the GSTO1 A140D polymorphism in either group fitted the Hardy-Weinberg equilibrium model. Multivariate logistic regression (34) was used to calculate the odds ratios (OR) and $95 \%$ confidence intervals between the genotypes and lung cancer, adjusted for smoking status, sex, and age. $P$ values less than 0.05 were assumed to be significant.

\section{RESULTS AND DISCUSSION}

Allele frequencies and genotype distribution of the GSTO1 A140D polymorphism in our study significantly differ from those of African, Brazilian, and Eastern Asian populations and are similar to other Caucasian populations (Table 1). In addition, our results are in contrast with the findings for the Turkish population reported by Takeshita et al. (17), whose genotype distribution and allele frequencies are similar to those 
of African, Brazilian, and Eastern Asian populations. This is rather unexpected because polymorphism frequencies of xenobiotic metabolising enzyme genes studied in the Turkish population so far, namely CYP, $\mathrm{mEH}$, and GST, are generally similar to other Caucasian populations $(20-22,35)$. At this stage, we can only speculate about the reasons why our findings differ, as both studies used the same methods, and sample sizes were similar. However, Takeshita et al. (17) have not included important demographic information on their Turkish native-borns such as age, sex, race, and exclusion criteria with respect to the health status. The only information they have provided is that their population included native-borns of the

Table 1 Allele frequencies and genotype distribution of the GSTO1 A140D polymorphism in different populations

\begin{tabular}{|c|c|c|c|c|c|c|c|}
\hline \multirow{2}{*}{ Population } & \multirow{2}{*}{$\mathbf{n}$} & \multicolumn{2}{|c|}{ Allele frequency } & \multicolumn{3}{|c|}{ Genotype / $n(\%)$} & \multirow[t]{2}{*}{ Reference } \\
\hline & & A140 & D140 & $\mathbf{A} / \mathbf{A}$ & A/D & $\mathrm{D} / \mathrm{D}$ & \\
\hline German & 280 & 0.680 & 0.320 & $126(46)$ & $129(46)$ & $25(9)$ & 14 \\
\hline Italian & 116 & 0.698 & 0.302 & $50(43)$ & $62(53)$ & $4(3)$ & 18 \\
\hline White American & 735 & 0.655 & 0.345 & $319(44)$ & $315(43)$ & $93(13)$ & 12 \\
\hline White American & 220 & 0.666 & 0.334 & $96(44)$ & $101(46)$ & $23(11)$ & 15 \\
\hline European Australian & 100 & 0.665 & 0.335 & $45(45)$ & $43(43)$ & $12(12)$ & 8 \\
\hline Chinese & 215 & 0.853 & $0.137 *$ & $158(73)$ & $55(26)$ & $2(1)$ & 16 \\
\hline Chinese & 100 & 0.835 & $0.165^{*}$ & $71(71)$ & $25(25)$ & $4(4)$ & 8 \\
\hline Thai & 98 & 0.870 & $0.130 *$ & $74(76)$ & $23(23)$ & $1(1)$ & 13 \\
\hline African & 62 & 0.919 & $0.081 *$ & $52(84)$ & $10(16)$ & $0(0)$ & 8 \\
\hline Japanese & 102 & 0.892 & $0.108 *$ & $81(79)$ & $20(20)$ & $1(1)$ & 17 \\
\hline Mongol & 243 & 0.872 & $0.128 *$ & $183(75)$ & $58(24)$ & $2(1)$ & 17 \\
\hline Ovambo (Namibia) & 163 & 0.960 & $0.040^{*}$ & $150(92)$ & $13(8)$ & $0(0)$ & 17 \\
\hline Brazilian & 173 & 0.899 & $0.101^{*}$ & $146(84)$ & $19(11)$ & $8(5)$ & 11 \\
\hline Turkish & 194 & 0.915 & $0.085^{*}$ & $162(83)$ & $31(16)$ & $1(1)$ & 17 \\
\hline Turkish & 214 & 0.689 & 0.311 & $104(48)$ & $87(41)$ & $23(11)$ & This study \\
\hline
\end{tabular}

* Significantly different when compared to this study $(\mathrm{P}<0.05)$.

Table 2 Characteristics of the study population

\begin{tabular}{lcc}
\hline & NSCLC patients $(\boldsymbol{n}=\mathbf{1 7 2})$ & Healthy controls $(\boldsymbol{n}=\mathbf{2 1 4})$ \\
\hline Age / years & 56 & 49 \\
\hline Mean & 26 to 75 & 24 to 76 \\
\hline Range & & $118(55)$ \\
\hline Gender /n (\%) & $156(91)$ & $96(45)$ \\
\hline Male & $16(9)$ & $87(41)$ \\
\hline Female & & $43(20)$ \\
\hline Smoking status /n (\%) & $15(9)$ & $84(39)$ \\
\hline Never & $55(32)$ & 15 \\
\hline Former & $102(59)$ & $48(104)$ \\
\hline Current & 56 & $41(87)$ \\
\hline Pack-years, mean* & & $11(23)$ \\
\hline Genotypes /n (\%) & $48(82)$ & \\
\hline A/A & $45(77)$ & \\
\hline A/D & $7(13)$ & \\
\hline D/D & & \\
\hline NSCLC stage /n (\%) & \\
\hline III & $77(45)$ & \\
\hline IV & $95(55)$ & \\
\hline Tumor histology/n $(\%)$ & & \\
\hline SCC & $65(38)$ & \\
\hline AC & $59(34)$ & \\
\hline UNSCLC & $48(28)$ & \\
\hline Among ever smokers & & \\
\hline
\end{tabular}


Table 3 Combined effects of polymorphisms and smoking on NSCLC risk

\begin{tabular}{|c|c|c|c|c|c|}
\hline GSTO1 genotype & Smoking & Control / $n$ & Case / $n$ & OR $(95 \%$ CI $) *$ & $P$ \\
\hline $\mathrm{A} / \mathrm{A}$ & Never & 45 & 8 & 1 & \\
\hline $\mathrm{A} / \mathrm{A}$ & Ever & 59 & 74 & $3.58(1.39$ to 9.21$)$ & 0.008 \\
\hline $\mathrm{A} / \mathrm{D}+\mathrm{D} / \mathrm{D}$ & Never & 42 & 7 & $1.01(0.32$ to 3.14$)$ & 0.987 \\
\hline $\mathrm{A} / \mathrm{D}+\mathrm{D} / \mathrm{D}$ & Ever & 68 & 83 & $5.63(2.15$ to 14.74$)$ & 0.000 \\
\hline $\mathrm{A} / \mathrm{D}+\mathrm{D} / \mathrm{D}$ & Never & 42 & 7 & 1 & \\
\hline $\mathrm{A} / \mathrm{D}+\mathrm{D} / \mathrm{D}$ & Ever & 68 & 83 & 5.54 (1.96 to 15.67$)$ & 0.001 \\
\hline $\mathrm{A} / \mathrm{A}$ & Ever & 59 & 74 & 1 & \\
\hline $\mathrm{A} / \mathrm{D}+\mathrm{D} / \mathrm{D}$ & Ever & 68 & 83 & $1.04(0.61$ to 1.76$)$ & 0.884 \\
\hline
\end{tabular}

*OR (odds ratio) and (95\% CI) confidence interval were calculated by multivariate logistic regression and adjusted for age and gender

city of Adana in Turkey, whose data they received from a German physician.

Characteristics of the study population are presented in Table 2. As a group, NSCLC patients were older and had more smokers than controls $(P<0.05)$. In addition, they smoked much more than controls $(P<0.05)$. However, we did not find significant differences in the frequency of GSTO1 A/A (wild type), $A / D$ (heterozygous mutant), and $D / D$ (homozygous mutant) genotypes between NSCLC patients and controls, and they remained in the Hardy-Weinberg equilibrium ( $P=0.456 v$ v. $P=0.379$, respectively). No significant difference was also observed between men and women (data not shown).

We also looked into the distribution of GSTO1 genotypes by histological subtypes in NSCLC patients but saw no statistically significant difference between controls and NSCLC or histological subtypes (data not shown). Using multivariate logistic regression (MLR) analysis adjusted for age, sex, and smoking, we established that GSTO1 genotypes presented no risk for overall NSCLC or a particular histological subtype. Likewise, Granja et al. (11) and Marahatta et al. (13) did not find any association between this gene polymorphism and thyroid and colorectal cancers, respectively. Findings are still inconclusive and controversial, as some authors established an increased risk of breast, hepatocellular, bile duct and urothelial cancers, and acute lymphoblastic leukaemia in childhood in GSTO1 A140D mutant allele carries $(13,23-25)$ while more recent studies on breast cancer report no such association $(36,37)$.

Using MLR, we also established that smoking did not influence the relationship between GSTO1 A140D and the risk of NSCLC (Table 3). However, smoking alone, independent of the genotype, significantly increased the risk of NSCLC (Table 2). Likewise,
Olsen et al. (23) could not detect any interaction between cigarette smoking and GSTO1 A140D in breast cancer, nor could Ada et al. (33) and Schneider et al. (38) establish an association between cigarette smoking and other GST polymorphisms in lung cancer, including NSCLC.

Our study may be limited by the sample size, especially in the analysis of the association between the polymorphism and cancer risk in the histological subtypes. However, this is the first report showing that the frequency of the GSTO1 A140D gene polymorphism in the Turkish population is similar to other Caucasian populations and that this polymorphism is not associated with susceptibility to NSCLC. Further research with a larger sample size is needed to verify this finding.

\section{Acknowledgement}

This research was supported by the Research Fund of Ankara University (project number: 2008-08-03006HPD).

\section{REFERENCES}

1. Autrup H. Gene-environment interactions in environmental carcinogens. In: Nicolopoulou-Stamati P, Hens L, Howard $\mathrm{CV}$, Van Larebeke N, editors. Cancer as an environmental disease. Dordrecht: Kluwer Academic Publisher; 2004. p. 71-101.

2. Strange RC, Spiteri MA, Ramachandran S, Fryer AA. Glutathione-S-transferase family of enzymes. Mutat Res 2001;482:21-6.

3. Yin ZL, Dahlstrom JE, Le Couteur DG, Board PG. Immunohistochemistry of omega class glutathione Stransferase in human tissues. J Histochem Cytochem 2001:49:983-7. doi: 10.1177/002215540104900806

4. Harju TH, Peltoniemi MJ, Rytilä PH, Soini Y, Salmenkivi KM, Board PG, Ruddock LW, Kinnula VL. Glutathione S- 
transferase omega in the lung and sputum supernatants of COPD patients. Respir Res 2007;8:48. doi:10.1186/14659921-8-48

5. Dulhunty A, Gage P, Curtis S, Chelvanayagam G, Board P. The glutathione transferase structural family includes a nuclear chloride channel and a ryanodine receptor calcium release channel modulator. J Biol Chem 2001;276:3319-23. doi: $10.1074 /$ jbc.M007874200

6. Wang L, Xu J, Ji C, Gu S, Lv Y, Li S, Xu Y, Xie Y, Mao Y. Cloning, expression and characterization of human glutathione S-transferase Omega 2. Int J Mol Med 2005;16:19-27.

7. Board PG. The omega-class glutathione transferases: structure, function, and genetics. Drug Metab Rev 2011;43:226-35. doi: 10.3109/03602532.2011.561353

8. Tanaka-Kagawa T, Jinno H, Hasegawa T, Makino Y, Seko Y, Hanioka N, Ando M. Functional characterization of two variant human GSTO 1-1s (Ala140Asp and Thr217Asn). Biochem Biophys Res Commun 2003;301:516-20.

9. Whitbread AK, Tetlow N, Eyre HJ, Sutherland GR, Board PG. Characterization of the human Omega class glutathione transferase genes and associated polymorphisms. Pharmacogenetics 2003;13:131-44. doi: 10.1097/01. fpc.0000054062.98065.6e

10. Board PG, Anders MW. Glutathione transferase omega 1 catalyzes the reduction of S-(phenacyl)glutathiones to acetophenones. Chem Res Toxicol 2007;20:149-54. doi: $10.1021 /$ tx $600305 y$

11. Granja F, Morari EC, Assumpção LV, Ward LS. GSTO polymorphism analysis in thyroid nodules suggest that GSTO1 variants do not influence the risk for malignancy. Eur J Cancer Prev 2005;14:277-80.

12. Ozturk A, Desai PP, Minster RL, Dekosky ST, Kamboh MI Three SNPs in the GSTO1, GSTO2 and PRSS11 genes on chromosome 10 are not associated with age-at-onset of Alzheimer's disease. Neurobiol Aging 2005;26:1161-5. doi: 10.1016/j.neurobiolaging.2004.11.001

13. Marahatta SB, Punyarit P, Bhudisawasdi V, Paupairoj A, Wongkham S, Petmitr S. Polymorphism of glutathione Stransferase omega gene and risk of cancer. Cancer Lett 2006;236:276-81. doi: 10.1016/j.canlet.2005.05.020

14. Kölsch H, Linnebank M, Lütjohann D, Jessen F, Wüllner U, Harbrecht U, Thelen KM, Kreis M, Hentschel F, Schulz A, von Bergmann K, Maier W, Heun R. Polymorphisms in glutathione S-transferase omega-1 and AD, vascular dementia, and stroke. Neurology 2004;63:2255-60. doi: 10.1212/01.WNL.0000147294.29309.47

15. Wahner AD, Glatt CE, Bronstein JM, Ritz B. Glutathione S-transferase mu, omega, pi, and theta class variants and smoking in Parkinson's disease. Neurosci Lett 2007;413:2748. doi: 10.1016/j.neulet.2006.11.053

16. Fu S, Wu J, Chen F, Sun D, Fu S. Polymorphisms of Glutathione S-transferases Omega-1 among ethnic populations in China. BMC Genet 2008;9:29. doi: 10.1186/1471-21569-29

17. Takeshita H, Fujihara J, Takastuka H, Agusa T, Yasuda T, Kunito T. Diversity of glutathione s-transferase omega 1. A140D; and 2. N142D; gene polymorphisms in worldwide populations. Clin Exp Pharmacol Physiol 2009;36:283-6. doi: 10.1111/j.1440-1681.2008.05058.x

18. Polimanti R, Piacentini S, Porreca F, Fuciarelli M. Glutathione S-transferase $\omega$ class. GSTO; polymorphisms in a sample from Rome (Central Italy). Ann Hum Biol 2010;37:585-92. doi: 10.3109/03014460903508520

19. Kunak SC, Ada AO, Karacaoglan V, Soydas E, Bilgen S, Iscan M. Drug/xenobiotic metabolizing enzyme polymorphisms in a Turkish population. Afr J Pharm Pharmacol 2012;6:2068-74. doi: 10.5897/AJPP12.339

20. Peter H, Deutschmann S, Reichel C, Hallier E. Metabolism of methyl chloride by human erythrocytes. Arch Toxicol 1989;63:351-5. doi: 10.1007/BF00303122

21. Garte S, Gaspari L, Alexandrie AK, Ambrosone C, Autrup H, Autrup JL, Baranova H, Bathum L, Benhamou S, Boffetta P, Bouchardy C, Breskvar K, Brockmoller J, Cascorbi I, Clapper ML, Coutelle C, Daly A, Dell'Omo M, Dolzan V, Dresler CM, Fryer A, Haugen A, Hein DW, Hildesheim A, Hirvonen A, Hsieh LL, Ingelman-Sundberg M, Kalina I, Kang D, Kihara M, Kiyohara C, Kremers P, Lazarus P, Le Marchand L, Lechner MC, van Lieshout EM, London S, Manni JJ, Maugard CM, Morita S, Nazar-Stewart V, Noda K, Oda Y, Parl FF, Pastorelli R, Persson I, Peters WH, Rannug A, Rebbeck T, Risch A, Roelandt L, Romkes M, Ryberg D, Salagovic J, Schoket B, Seidegard J, Shields PG, Sim E, Sinnet D, Strange RC, Stücker I, Sugimura H, To-Figueras J, Vineis P, Yu MC, Taioli E. Metabolic gene polymorphism frequencies in control populations. Cancer Epidemiol Biomarkers Prev 2001;10:1239-48

22. Aktas D, Ozen H, Atsu N, Tekin A, Sozen S, Tuncbilek E. Glutathione S-transferase M1 gene polymorphism in bladder cancer patients. A marker for invasive bladder cancer? Cancer Genet Cytogenet 2001;125:1-4.

23. Olsen A, Autrup H, Sørensen M, Overvad K, Tjønneland A. Polymorphisms of glutathione S-transferase $\mathrm{A} 1$ and $\mathrm{O} 1$ and breast cancer among postmenopausal Danish women. Eur J Cancer Prev 2008;17:225-9. doi: 10.1097/ CEJ.0b013e3282b6fele

24. Pongstaporn W, Pakakasama S, Sanguansin S, Hongeng S, Petmitr S. Polymorphism of glutathione S-transferase Omega gene: association with risk of childhood acute lymphoblastic leukemia. J Cancer Res Clin Oncol 2009;135:673-8. doi: 10.1007/s00432-008-0501-4

25. Wang YH, Yeh SD, Shen KH, Shen CH, Juang GD, Hsu LI, Chiou HY, Chen CJ. A significantly joint effect between arsenic and occupational exposures and risk genotypes/ diplotypes of CYP2E1, GSTO1 and GSTO2 on risk of urothelial carcinoma. Toxicol Appl Pharmacol 2009;241:1118. doi: 10.1016/j.taap.2009.08.008

26. Dubey S, Powell CA. Update in lung cancer 2007. Am J Respir Crit Care Med 2008;177:941-6. doi: 10.1164/ rccm.200801-107UP

27. Yanbaeva DG, Wouters EF, Dentener MA, Spruit MA, Reynaert NL. Association of glutathione-S-transferase omega haplotypes with susceptibility to chronic obstructive pulmonary disease. Free Radic Res 2009;43:738-43. doi: 1 0.1080/10715760903038440

28. Hu YC, Sidransky D, Ahrendt SA. Molecular detection approaches for smoking associated tumors. Oncogene 2002;21:7289-97. doi: 10.1038/sj.onc.1205805

29. Chan EC, Lam SY, Fu KH, Kwong YL. Polymorphisms of the GSTM1, GSTP1, MPO, XRCC1, and NQO1 genes in Chinese patients with non-small cell lung cancers: relationship with aberrant promoter methylation of the CDKN2A and RARB genes. Cancer Genet Cytogenet 2005;62:10-20. 
30. Hoffmann D, Rivenson A, Murphy SE, Chung F-L, Amin S, Hecht SS. Cigarette smoking and adenocarcinoma of the lung: the relevance of nicotine-derived $N$-nitrosamines. J Smoking Rel Disord 1993;4:165-90.

31. Denissenko MF, Pao A, Tang M-S, Pfeifer GP. Preferential formation of benzo[a]pyrene adducts at lung cancer mutational hotspots in $p 53$. Science 1996;274:430-2. doi: 10.1126/science. 274.5286 .430

32. Ada AO, Kunak SC, Hancer F, Bilgen S, Suzen SH, Alpar S, Gulhan M, Kurt B, Iscan M. CYP and GST polymorphisms and survival in advanced non-small cell lung cancer patients. Neoplasma 2010;57:512-21.

33. Ada AO, Kunak SC, Hancer F, Soydas E, Alpar S, Gulhan M, Iscan M. Association between GSTM1, GSTT1, and GSTP1 polymorphisms and lung cancer risk in a Turkish population. Mol Biol Rep 2012;39:5985-93. doi: 10.1007/ s11033-011-1411-0

34. Breslow NE, Day NE, editors. Statistical Methods in Cancer Research. Volume I - The Analysis of Case-Control Studies. IARC Sci Publ No. 32. Lyon: IARC; 1980.
35. Ulusoy G, Arinç E, Adali O. Genotype and allele frequencies of polymorphic CYP2E1 in the Turkish population. Arch Toxicol 2007;81:711-8. doi: 10.1007/s00204-007-0200-y

36. Chariyalertsak S, Purisa W, Sangrajrang S. Role of glutathione S-transferase omega gene polymorphisms in breast-cancer risk. Tumori 2009;95:739-43. doi: 10.1700/467.5515

37. Andonova IE, Justenhoven C, Winter S, Hamann U, Baisch C, Rabstein S, Spickenheuer A, Harth V, Pesch B, Brüning T, Ko YD, Ganev V, Brauch H. No evidence for glutathione S-transferases GSTA2, GSTM2, GSTO1, GSTO2, and GSTZ1 in breast cancer risk. Breast Cancer Res Treat 2010;121:497-502. doi: 10.1007/s10549-009-0589-5

38. Schneider J, Bernges U, Philipp M, Woitowitz HJ. GSTM1, GSTT1, and GSTP1 polymorphism and lung cancer risk in relation to tobacco smoking. Cancer Lett 2004;208:65-74. doi: $10.1016 /$ j.canlet.2004.01.002 


\section{Sažetak}

POVEZANOST POLIMORFIZMA A140D GENA GLUTATION S-TRANSFERAZE OMEGA 1 I OSJETLJIVOSTI NA RAK PLUĆA NE-MALIH STANICA U TURSKOG STANOVNIŠTVA

Posljednjih godina sve više rezultata ispitivanja upozorava na rasne razlike u učestalosti polimorfizma A140D gena glutation S-transferaze omega 1 (GSTO1) koji je povezan s više oblika karcinoma, poput raka dojke i jetara. Dosada međutim nije ispitana povezanost GSTO1 A140D i raka pluća. Mi smo u ovom ispitivanju pokušali utvrditi postoji li takva povezanost u turskog stanovništva. Izdvojili smo 214 zdravih ispitanika koji nisu bili u rodu te 172 bolesnika s rakom pluća ne-malih stranica, u kojih je polimorfizam GSTO1 A140D utvrđen pomoću lančane reakcije polimerazom - cijepanjem restrikcijskim enzimima (PCR/RFLP). Učestalost GSTO1 A140D genotipova - divljeg tipa (A/A), heterozigotnog mutanta (A/D) odnosno homozigotnog mutanta (D/D) - u zdravih ispitanika iznosila je $48 \%$, $41 \%$, odnosno $11 \%$, a u bolesnika s rakom pluća ne-malih stanica $48 \%$, $45 \%$ odnosno $7 \%$. Rezultati ispitivanja nisu pokazali značajne povezanosti između genskog polimorfizma GSTO1 A140D i raka pluća ne-malih stanica odnosno njegovih histoloških podtipova raka pločastih stanica ili adenokarcinoma. Također nisu pokazali povezanost između ovog polimorfizma i pušenja. Međutim, ovo je prvo ispitivanje koje je potvrdilo da učestalost GSTO1 A140D u turske populacije odgovara učestalosti pripadnika bijele (kavkaske) rase te da nije povezan s osjetljivosti na rak pluća ne-malih stanica.

KLJUČNE RIJEČI: adenokarcinom, bijela rasa, genski polimorfizam, rak pločastih stanica, rasne razlike

\section{CORRESPONDING AUTHOR:}

Mumtaz Iscan, Ph.D.

Department of Toxicology

Faculty of Pharmacy, Ankara University 06100 Tandogan, Ankara, Turkey

E-mail: iscan@pharmacy.ankara.edu.tr 